\title{
Observations on Heterosis in Zea mays L. II.
}

Obserwacje nad heterozją u Zea mays L. II.

\section{HELENA BAÑKOWSKA}

This work is a continuation of the research on heterosis in maize, carried out in the Department of Genetics of the Warsaw University of Agriculture. The experiment was performed in 1961, its purpose, was to investigate the hereditary characters of the vigorous line No. 10 isolated by means of inbreeding the most vigorous plants in $\mathrm{F}_{2}$ and succeeding generations of crossed inbred lines WD and W9. It seems that the possibility of selecting lines with a fixed vigorous growth from the progeny of crosses between inbreds exhibiting a high combining ability — should be taken into consideration for breeding purpose. In the production of hybrid seed such lines should be used by way of crossing with other inbreds.

The starting material for this research consisted of inbred lines WD and W9, first hybrid generation and line No. 10 with a fixed vigorous growth. Several crosses were done between line No. 10 and parental inbred lines WD and W9, also with $\mathrm{F}_{1}$. Moreover, backcrosses of $\mathrm{F}_{1}$ with inbred lines WD and W9 were also performed. The experimental material used in this study embraced 935 plants. The plants grew in $80 \times 70 \mathrm{~cm}$ rows in rich soil well fertilized. At the end of August measurements were taken of the height of plants, length and width of leaves on the main stem.

The viability of pollen grains was examined for the relation between vigorous growth and a greater per cent of normal pollen grains. In this purpose the percentage of fully developed pollen grains was computed in the parental lines WD and W9, in $F_{1}$ and in line No. 10, the samples of pollen being collected from tassels in full flowering. The computations of the percentage of normally developed pollen was based on the examination of 20 fields of view of each plant with 10 plants being taken at random out of each investigated line.

The surface of the leaf blades on the main stem of each plant was computed according to Montgo m ery's formula (T a v č a r, 1939). Next the total sum of the leaf surfaces on the main stem for each plant was 
computed. The arithmetic mean values were obtained from the experimental data.

Table 1

Mean height of plants in $\mathrm{cm}$ at the end of vegetation

\begin{tabular}{|c|c|c|c|}
\hline Line No. 10 & $\mathrm{F}_{1}(\mathrm{WD} \times \mathrm{W} 9)$ & Line W9 & Line WD \\
\hline $220 \pm 2.16$ & $163.53 \pm 1.23$ & $129.27 \pm 1.28$ & $114.10 \pm 1.01$ \\
\hline
\end{tabular}

Comparison of arithmetic mean values in the progeny of crosses:

\begin{tabular}{|c|c|c|c|c|}
\hline Line No. $10 \times \mathrm{F}_{1}$ & l. No. $10 \times \mathrm{W} 9$ & No. $10 \times \mathrm{WD}$ & $\mathrm{F}_{1} \times \mathrm{W} 9$ & $\mathrm{~F}_{1} \times \mathrm{WD}$ \\
\hline $207.68 \pm 1.35$ & $191.28 \pm 9.26$ & $187.64 \pm 3.13$ & $157.18 \pm 1.06$ & $145.53 \pm 1.28$ \\
\hline \multirow{3}{*}{ Differences } & $16.40^{*}$ & $20.04^{*}$ & $50.50^{*}$ & $62.15^{*}$ \\
\cline { 2 - 5 } & & 3.64 & $34.10^{*}$ & $45.75^{*}$ \\
\cline { 2 - 5 } & & & $30.46 *$ & $42.11^{*}$ \\
\hline
\end{tabular}

On the basis of the observations on the percentage of normally developed pollen grains and computation of the experimental data it was possible to establish that the scale of variance for this trait in inbred line WD amounts from 65 to $85 \%$ (the arithmetic mean $\overline{\mathrm{x}}=77.5 \pm 6.45 \%$ ), in line W9: from 70 to $90 \%$ ( $\overline{\mathrm{x}}=85.0 \pm 6.55 \%)$,in $\mathrm{F}_{1}$ : from 85 to $100 \%$ $(\overline{\mathrm{x}}=93.37 \pm 3.75 \%)$ and in line No. $10:$ from 30 to $90 \%(\overrightarrow{\mathrm{x}}=86.7 \pm$ $\pm 2.05 \%)$. From the above it may be seen that the average per cent of normally developed pollen grains in $\mathrm{F}_{1}$ has increased considerably in comparison with the parental lines - this proves an increase of viability in $\mathrm{F}_{1}$. Line No. 10, in spite of a most pronounced vigorous growth, is inferior in this respect in comparison with $F_{1}$ - this fact points to no dependens of pollen viability on the vigourous growth of plants.

In regard to the height of plants the data are given in Table 1. The upper row presents data expressing the arithmetic mean values in $\mathrm{cm}$ for the height of plants at the end of August. These data show distinctly that line No. 10 is superior in height in respect to the parental lines and $F_{1}$. That this kind of vigorous growth of line No. 10 is a hereditary fixed may be proved comparing the arithmetic mean values for the progeny of the crosses between line No. 10 and parental lines WD and W9 - and the arithmetic mean values for backcrosses between the same parental lines and $\mathrm{F}_{1}$.

The following rows presented in Table 1 give the arithmetic mean values and their differences for the height of the progeny plants obtained from backcrosses and crosses between line No. 10 and parental lines WD, W9 and also $F_{1}$. All the differences are significant. The difference bet- 
ween the arithmetic mean values for "W9 $\times$ No. 10 " and "WD $\times$ No. 10 " crosses is an exception it amounts to only $3.64 \mathrm{~cm}$ and is not significant. As concerns the mean height of the backcross progeny it appears to be smaller in crosses with WD than with W9 ( $\overline{\mathrm{x}}$ amounts to: for $\mathrm{F}_{1} \times \mathrm{W} 9=$ $=157.18 \mathrm{~cm}$, for $F_{1} \times W D=145.53 \mathrm{~cm}$ ). Thus the height differences remained in the same proportion to the differences between inbreds W9 and WD.

The difference between mean values appears to be similar in crosses between parental lines and vigorous line No. 10. It was possible to observe in this case that it is proportional to the difference between inbreds W9 and WD, however it has not been statistically proved (at the level $\mathrm{p}=0.05)$.

If we assume that the vigorous growth of line No. 10 is hereditary fixed - then in crosses of this line with $\mathrm{F}_{1}$ (WD $\times$ W9) the height of progeny plants should be the greatest. Experimental data have proved this assumption to be right. Crosses of $F_{1}$ with line No. 10 have given in effect plants much higher than in other crosses, however their height did not exceed the height of plants of line No. 10, the vigour of which, as it is known, is not connected with the stimulating effect of heterozygous state.

Table 2

Mean values for the sum of leaf surfaces on the main stem in $\mathrm{cm}$

\begin{tabular}{|c|c|c|c|}
\hline Line No. 10 & $\mathrm{F}_{1}(\mathrm{WD} \times \mathrm{W} 9)$ & W9 & WD \\
\hline $4455 \pm 65.6$ & $2730 \pm 44.1$ & $2075 \pm 51.8$ & $1995 \pm 37.7$ \\
\hline
\end{tabular}

Comparison of arithmetic mean values in the progeny of crosses:

\begin{tabular}{|c|c|c|c|c|}
\hline $4225 \pm 54.3$ & $3750 \pm 128.6$ & $3570 \pm 102.3$ & $2430 \pm 29.6$ & $2360 \pm 41.8$ \\
\hline \multirow{3}{*}{ Differences } & $475^{*}$ & $655^{*}$ & $1795^{*}$ & $1865^{*}$ \\
\cline { 2 - 5 } & & 180 & $1320^{*}$ & $1390^{*}$ \\
\cline { 2 - 5 } & & & $1140^{*}$ & $1210^{*}$ \\
\hline & & & & 70 \\
\hline
\end{tabular}

The data bearing on the feature, characterizing the total sum of the leaf surfaces of the main stem, are presented in Table 2. The upper row of the Table gives the data concerning the arithmetic mean values for line No. $10, F_{1}$ and parental inbreds $\mathrm{W} 9$ and WD. These data show that line No. 10 distinctly prevails over $F_{1}$ and inbred lines. The next rows of the Table plot the arithmetic mean values and differences between them for progeny plants obtained from backcrosses, also from crosses performed between vigorous line No. 10 and inbreds W9 and WD as well as with $F_{1}$. The differences between the arithmetic mean values are significant with the exception of the difference of crosses performed between 
line No. 10 and W9 and also between WD, as well as between backcrosses: $F_{1} \times W 9$ and $F_{1} \times W D$. The absence of significant differences in this case is connected with a rather indistinct accentuation of the prevailence in the growth of plants of the line W9 in regard to those of the line WD. Perhaps it may have been caused by the abnormal atmospheric conditions in 1961.

The vigorous growth expressed by the arithmetic mean value of the total sum of leaf blade surfaces in the progeny of the cross between line No. 10 and $F_{1}$ - shows a distinct prevailence in comparison with the mean values of progeny plants of crosses between this line and the inbreds W9 and WD as well as of backcrosses with $\mathrm{F}_{1}$.

On the basis of experimental results it was possible to state that $F_{1}$ (W9 $\times$ WD) show vigorous growth in connection with the height of plants and the total sum of leaf surfaces on the main stem. Line No. 10, isolated from the most vigorous plants of the $\mathrm{F}_{2}$ and succeeding generations has exhibited in crosses with $\mathrm{F}_{1}$ and inbreds W9 and WD a considerable predominance in vigour in comparison with the progeny obtained from backcrosses between parental lines and $F_{1}$. On this basis it may be stated that line No. 10 represents a stable line with a hereditary fixed vigorous growth.

Department of Genetics, Warsaw Agricultural University, Poland

(Entered: 25.II.1964)

\section{STRESZCZENIE}

Badania nad heterozją u kukurydzy prowadzone są w Zakładzie Genetyki S.G.G.W.

W doświadczeniu wykonanym w celu zbadania własności dziedzicznych bujnej linii No 10 materiał eksperymentalny obejmował 935 osobników.

Wykonano szereg krzyżówek między linią No 10 a wyjściowymi liniami wsobnymi rodzicielskimi $\mathrm{W} 9 \mathrm{i} \mathrm{WD}$, a także mieszańcami $\mathrm{F}_{1}$. Ponadto przeprowadzono wsteczne krzyżówki mieszańców $\mathrm{F}_{1}$ z liniami WD i W9. Obserwacjom poddano cechę wysokości roślin w końcowym okresie wegetacji, rozmiary liści i sumę ich powierzchni na pędzie glównym. Na podstawie danych eksperymentalnych stwierdzono wyraźną przewagę $\mathrm{w}$ bujności mieszańców uzyskanych ze skrzyżowania $F_{1}$ z bujną linią No 10, w stosunku do potomstwa pozostałych krzyżówek. Srednie arytmetyczne dla cech wyrażających bujność mieszańców otrzymanych w wyniku krzyżowania linii No 10 z liniami wsobnymi WD i W9, wykazują istotną przewazę w stosunku do odnośnych średnich w potomstwie krzyżówek $F_{1}$ z tymi samymi liniami wsobnymi. Różnice te są istotne i statystycznie udowodnione.

Na tej podstawie można wyciągnąc wniosek, że linia No 10 reprezentuje linię z dziedzicznie utrwaloną bujnością. 


\section{REFERENCES}

1. Malinowski E., H. Bańkowska and M. Biurkowska, 1960, Heterosis in Maize (Zea mays). I. Correlation phenomena between vigorous growth and time of flowering in $\mathrm{F}_{2}$. Bul. Ac. Pol. Sci. Cl. II, 8 (1).

2. Malinowski E., H. Bańkowska and M. Biurkowska, 1960, Heterosis in Maize (Zea mays). II. Fixing vigorous growth, Bul. Ac. Pol. Sci. Cl. II, 8 (1).

3. B ańkowska H., 1964, Observations on heterosis in Zea mays L., Acta Agrobotanica 15 .

4. Tavíar A., 1939, Mais, Handbuch der Pflanzenzüchtung II B. Bog. 1-̄̄. 